\section{DIGITAL COMMONS \\ @ UNIVERSITY OF SOUTH FLORIDA}

\section{ABO: Interactive Journal for Women in the Arts, 1640-1830}

Volume 8

Issue 1 Spring 2018

Article 2

2018

\title{
Anna Larpent and Shakespeare
}

Fiona Ritchie

McGill University, fiona.ritchie@mcgill.ca

Follow this and additional works at: https://digitalcommons.usf.edu/abo

Part of the Dramatic Literature, Criticism and Theory Commons, Educational Methods Commons, European History Commons, Feminist, Gender, and Sexuality Studies Commons, History of Gender Commons, Literature in English, British Isles Commons, and the Theatre History Commons

\section{Recommended Citation}

Ritchie, Fiona (2018) "Anna Larpent and Shakespeare," ABO: Interactive Journal for Women in the Arts, 1640-1830: Vol.8: Iss.1, Article 2. https://doi.org/10.5038/2157-7129.8.1.1152

Available at: https://digitalcommons.usf.edu/abo/vol8/iss1/2

This Scholarship is brought to you for free and open access by Digital Commons @ University of South Florida. It has been accepted for inclusion in ABO: Interactive Journal for Women in the Arts, 1640-1830 by an authorized administrator of Digital Commons @ University of South Florida. For more information, please contact digitalcommons@usf.edu. 


\title{
Anna Larpent and Shakespeare
}

\begin{abstract}
Anna Larpent (1758-1832) is a crucial figure in theater history and the reception of Shakespeare since drama was a central part of her life. Larpent was a meticulous diarist: the Huntington Library holds seventeen volumes of her journal covering the period 1773-1830. These diaries shed significant light on the part Shakespeare played in her life and contain her detailed opinions of his works as she experienced them both on the page and on the stage in late eighteenth- and early nineteenth-century London. Larpent experienced Shakespeare's works in a variety of forms: she sees Shakespeare's plays performed, both professionally and by amateurs; she reads his works and hears them read aloud by her husband and sons; she studies criticism of Shakespeare and records her reflections on it; she notes in her reading of contemporary writers when she feels they have been influenced by Shakespeare; she compares Shakespeare's plays with those of the pre-eminent French dramatist Voltaire; she reflects on various elements of Shakespeare's dramaturgy, such as his use of the supernatural; and she invokes Shakespeare in her ideas about education. This article has two aims. Firstly, an analysis of Larpent's engagement with Shakespeare demonstrates just how much the dramatist's works permeated the life of bourgeois woman of the period. Secondly, I explore how this deep interest in Shakespeare, which was not in itself altogether unusual, enabled Larpent to take on a less conventional role, that of censor. As the wife of the Examiner of Plays, Larpent influenced the licensing of drama for the London stage.
\end{abstract}

\section{Keywords}

Shakespeare, women, theatre, performance, reading, literary criticism

\section{Creative Commons License}

(c) (i) $\ominus$

This work is licensed under a Creative Commons Attribution-No Derivative Works 3.0 License.

\section{Cover Page Footnote}

I am indebted to the Huntington Library for a two-month fellowship that allowed me to study Larpent's diaries and I thank Diana Solomon for her comments on previous drafts of this article. 


\section{ANNA LARPENT AND SHAKESPEARE}

Fiona Ritchie, McGill University

Anna Margaretta Larpent, née Porter (1758-1832) is a crucial figure in theater history and the reception of Shakespeare since drama was a central part of her life. Larpent was the daughter of Sir James Porter, the British ambassador at Constantinople, and his wife Clarissa Catherine, the eldest daughter of the Dutch ambassador there. After spending her early childhood in Turkey, Larpent returned to England with her family in 1765 . Her mother died soon after but Larpent and her siblings enjoyed a cultured upbringing, "socializing with politicians and intellectuals, attending the theatre, and visiting historic landmarks." In 1782 she married John Larpent, who held the post of Examiner of Plays in the Office of the Lord Chamberlain from 1778 to 1824. Larpent "served as a sort of co-censor" with her husband and thus influenced the licensing of drama for the London stage. ${ }^{1}$ She was a meticulous diarist: the Huntington Library holds sixteen volumes of her journal, covering the period 1790 to 1830 , plus a further retrospective volume for the years 1773 to $1786 .{ }^{2}$ These diaries shed significant light on the part Shakespeare played in her life and contain her detailed opinions of his works as she experienced them both on the page and on the stage in late eighteenth- and early nineteenth-century London.

Larpent's first recorded exposure to Shakespeare occurs on 17 February 1773, when she saw David Garrick act the part of King Lear. She evaluates her experience as an audience member, noting that she was "never better entertained. too much so" (17:9r). ${ }^{3}$ The last reference to Shakespeare in Larpent's journals is on 25 April 1827, when she listened to her son George read aloud from Troilus and Cressida and Coriolanus (14:52v). Her diaries are full of references to her encounters with Shakespeare and these experiences take a variety of forms. For example, Larpent sees Shakespeare's plays performed, both professionally and by amateurs; she reads his works and hears them read aloud by her husband and sons; she studies criticism of Shakespeare and records her reflections on it; she notes in her reading of contemporary writers when she feels they have been influenced by Shakespeare; she compares Shakespeare's plays with those of the pre-eminent French dramatist Voltaire; she reflects on various elements of Shakespeare's dramaturgy, such as his use of the supernatural. Furthermore, Shakespeare was central to Larpent's ideas about education. Larpent also records her opinions of the plays submitted to her husband for licensing alongside her responses to Shakespeare. This article has two aims. Firstly, an analysis of Larpent's engagement with Shakespeare demonstrates just how much the dramatist's works permeated the life of a woman who, as John Brewer says, "personified a cultured lady of late eighteenth-century London" (Pleasures 56). Secondly, I explore how this deep interest in Shakespeare, which was not in itself altogether unusual, enabled Larpent to take on a less conventional role, that of dramatic censor.

\section{Shakespeare on the stage}

Even from a young age, Larpent's diaries analyze as well as record the Shakespeare that she saw performed. For example, the entry for 13 September 1777, when Larpent was 19 years old, comments specifically on acting: "At the play. the $1^{\text {st }}$. part of Henry the $4^{\text {th }}$. - Henderson acted Falstaff . . . I thought he forced it, \& showing too great anxiety to act it well, rendered it unnatural" $(17: 69 \mathrm{v})$. Her assessment here chimes with that of the critic Thomas Davies, who noted that, "Henderson had many difficulties to conquer before he could bring Falstaff within his 
grapple," although he eventually succeeded so that by 1783 Davies could claim that "in the frolicsome, gay, and humorous, situations of Falstaff, Henderson is superior to every man" (1:251-52). Larpent saw John Henderson in his first season on the London stage and her eagerness to evaluate this new performer in her diary suggests that she was equally keen to voice her opinion in more public spheres, for example in conversation with the family and friends who accompanied her on such visits to the playhouse.

Larpent's frequent trips to the theater also give us an excellent opportunity to compare actors' performances of a role over the course of their careers. On 20 March 1792, Larpent saw Sarah Siddons as Lady Macbeth and noted that "She acted well" but John Philip Kemble as Macbeth performed "stiffly. Trickfully. yet in one scene that preceding the Kings Murder Sensibly - he was perturbed, absent, $\&$ in a checked agitation that was well conceived" (1:45v). Here she gives not just a global assessment of Kemble's performance in the play as a whole, but also notes a particular scene in which she thought he shone. In his Macbeth Reconsidered of 1786, Kemble had taken pains to defend the character of Macbeth from Thomas Whately's accusations of cowardice by asserting that he was defined by intrepidity mixed with sensitivity. Larpent picks up on the way in which Kemble tried to perform the part not as a coward but as a feeling hero. When she saw the play again on 7 April 1795 at Drury Lane, Larpent had only praise for the actors (1:213v). And in reflecting on the performance at Covent Garden on 7 December 1803, Larpent is able to evaluate the actors' performances in comparison with their previous appearances in these roles:

$\mathrm{M}^{\mathrm{rs}}$ Siddons in Lady Macbeth I have seen act better. She is grown very large, \& was in the latter part too heavily dressed. Some parts She was great in. Kemble Was admirable in his figure \& often in his acting generally too Studied - the part preceding the discovery of Duncan's death he did extremely well \& When it was discovered. (5:151r)

She analyzes the progress of Siddons's career, suggesting that her talents were declining at this stage. Siddons had moved to Covent Garden that season when her brother took over as manager there but attempted no new roles from this point on (Highfill 28). Larpent's diary entry also confirms the popular contemporary assessment of John Philip Kemble as having the stage presence to perform the great Shakespearean roles but of sometimes being too "scientific" in his approach to portraying a character and unable to maintain prolonged displays of passion. Other critics agreed: Leigh Hunt, for example, wrote that, "Kemble, who is excellent in all that there is of dignity in Macbeth, cannot forget, in the more impassioned scenes, those methodistical artifices ... which always do and ever will injure his attempts at heartfelt nature" (22).

Crucially, Larpent comments on the full program of the evening's theatrical entertainment. For example, she notes the afterpiece, Alexander the Great; or, The Conquest of Persia by James D'Egville, following the performance of Macbeth that she saw in 1795: "Alexanders Conquest was afterwards. I have Seen it 3 times \& the puppet show tires" (1:213v). The Freemasons' Magazine for February 1795 described the piece as a "long-expected heroic Pantomime" and claimed that "this Ballet . . certainly exceeds every thing of the kind ever exhibited on an English Theatre" because of "the magnificent splendour of scenery and decorations" which "are happily and ingeniously blended with all that strength of interest which fine actions must ever excite" (135). It seems that the afterpiece was very much considered as a novelty, but one that 
easily wore off for Larpent: her dismissive comment on the piece as a "puppet show" suggests that she considered it as mere spectacle. ${ }^{4}$ She had a more favorable opinion of the farce Love Laughs at Locksmiths by George Colman the Younger that she saw after Macbeth in 1803: "The entertainment brings forward some of the Actors of farce with humour. They sustain their parts very well, $\&$ the whole made one laugh. $\mathbf{M}^{\mathrm{rs}}$ Creswell sings prettily" (5:151r). Here Larpent seems reluctant to ascribe much intellectual weight to the genre, perhaps because she found its potential to upset class hierarchies troubling, but nevertheless she recognizes the entertainment value of the piece. The double bill of mainpiece and afterpiece was standard practice in the period and the fact that Larpent gives details of both performances is extremely important: more critical comment survives on the longer mainpieces of the time but, even in the case of Shakespeare, it was often the spectacular afterpieces that drew the crowds. Indeed, theater managers often deemed afterpieces worthy of significant expenditure, which suggests that they expected such shows to yield high profits: Alexander the Great was rumored to have cost $£ 700$ to stage (Freemasons' Magazine 138).

Typical criteria addressed and evaluated by Larpent in her accounts of theatrical performance include, in addition to acting style, the physical conditions of the playhouse, scenery, costume, music, the emotional effect on the audience, and whether in general the play is fit for and successful in the theater. Her 1816 analysis of The Tempest, for example, examines not only the acting but also the scenery and music:

Saw the Tempest altered \& I think spoiled by Dryden then pruned by Garrick - The simplicity of the story $\&$ the interest of the Incidents altered into the vehicle of a brilliant Spectacle - The beauty \& execution of the Scenery are very fine - the new music not so, but the old songs by Purcell well introduced \& performed the Choruses particularly - The ballet part very showy. The silly love story introduced of Dorinda \& Hyppolito \& the equivoques it gives rise to are disgusting $\&$ to add to the absurdity a woman acted Hyppolito - The Aerial was Elegant \& sang very agreeably. Miss Macalpine. Calliban by Emery did not seem well understood he made him too ranting - Prospero by Young too Stiff \& Solemn. (9:284v-285r)

As theater manager, Kemble took great pains with the visual dimension of his Shakespeare productions, for example by employing a number of scene painters. In this account, Larpent also weighs in on the question of Shakespearean adaptation. This production's coupling of "brilliant spectacle" with the alterations made by Dryden and Davenant to the text is detrimental because the play loses its simplicity. She specifically objects to the addition of another romantic plot: in 1667, Dryden and Davenant had added a sister for Miranda named Dorinda in order to appeal to the neoclassical taste for symmetry. Dorinda's suitor, Hippolito, is a man who has never seen a woman and therefore parallels Miranda. The fact that Hippolito was conventionally played by a woman titillated Restoration audiences, to whom actresses were still a novelty, but almost a century and a half later, Larpent finds this absurd and distasteful. Larpent can here be seen entering into contemporary debate about the staging of Shakespeare's plays, addressing the question of whether the adaptations or the originals are more suitable for and successful in the theater. While Dryden and Davenant's version of The Tempest (with alterations by Garrick and Kemble) had endured, Larpent's account suggests that the critical tide was turning. Sure enough, William Charles Macready eventually removed the characters of Dorinda and Hippolito in his 
production of 1838 .

Larpent's diaries also take up another issue that preoccupied theater critics in the early nineteenth century: the merits of Master Betty, the famous boy actor, who debuted on the London stage in 1804 at the age of thirteen. Larpent saw him play the part of Hamlet on 29 April 1805 and her diary offers a full assessment:

Betty is a Beautiful Boy - too handsome to have much expression of countenance except from his admirable conception of the part he represents, from this, \& his self possession he gives much variety \& even emotion to his Countenance - he is in his action too studied - his Voice unformed is yet distinct, except sometimes in its falls. I was extremely struck with his management of some very Difficult parts, such as the one after he sees the Ghost ready to reveal the Secret to his friends then recollecting himself he turns off their enquiry this he does with admirable cleverness. - Also during the Mock play he shows great powers he certainly is an Extraordinary Boy. I differ from many - I think there is so much Mind about him \& such self command that he will improve not remain as he is or go off $\&$ if he lives be a superior Actor. (6:51r-51v)

Ultimately, it seems that the Young Roscius was unable to fulfill the potential that Larpent identified. He was apparently too arrogant and too complacent to work at improving his acting skill. Bettymania eventually began to wane, the actor's voice did not improve, and he was criticized for his ranting delivery, as well as the corpulence that destroyed the graceful stage presence for which he had been famous (Ranger). Nevertheless, Larpent's account of Betty's performance of Hamlet identifies his strengths in this role at a time when he was at the peak of his powers and reveals her eagerness to consider in detail the questions that were engrossing the London theater world of the day.

Despite the fact that Larpent's dramatic criticism appears in the apparently private form of the diary (and was not published so was unavailable to a large reading public), her assured tone shows her styling herself as a theatrical critic, considering all elements of both the play and the afterpiece performed with it, and offering her opinion on important contemporary debates. Although Larpent refers to her journal as "Chat with myself" (2:1r), Claire Miller Colombo notes that in the eighteenth century, "most diarists did not consider their diaries private documents, either in terms of audience or content" and claims that "the diarist typically wrote for a specified other - a consumer - and she [Larpent] often used her diary as a vehicle for entering into — or at least practicing - the public discourse from which she was by and large barred" (289). ${ }^{5}$ One volume of Larpent's diaries, the retrospective Methodized Journal, is dedicated to her husband and sister and she also notes that her sons (she had two children of her own and a stepson) "may get hints from [her] observations" (17:5r). It is clear that at the very least her family, possibly along with the friends with whom she shared her playgoing, were the intended consumers of her diaries. In fact, Larpent's writing style assumes the tone of an established and authoritative critic and the audience she has in mind seems to go beyond this intimate circle.

As her early assessment of Henderson's acting demonstrates, her critical voice is assured from the outset, but as the diaries continue her tone becomes increasingly confident. Elements of the presentation of her playgoing accounts in the manuscript diaries also demonstrate that she 
intended an audience for her comments. Early in the first volume she begins to present her opinions of the pieces she sees in quotation marks, singling them out as something particularly worth sharing with others. Furthermore, she often separates such remarks from her notes on the people who went with her or her enjoyment of the evening in general, as if trying to present an objective critique of the drama in the lines she highlights in this way. ${ }^{6}$ On 24 April 1792 she describes performances of John Home's Douglas and Catharine and Petruchio (Garrick's afterpiece adaptation of The Taming of the Shrew) as follows, using quotation marks in the margins to indicate her critical opinion:

... Evening again at the Play. With $\mathrm{M}^{\mathrm{rs}}$. and Miss Fremeaux \&c. $-M^{\text {rs }}$. Siddons in Lady Randolph in Douglas. I never was more painfully delighted. -

“ Douglas is a charming Poem in itself - Such admira-

“ ble Simplicity yet such Classical taste - Such beauty-

“ ful descriptions. - \& so well acted." After it we had

“ $\quad$ Catherine \& Petruchio. Much excellent Humour \&

“ entertainment.” A very pleasant Evening. (1:52r)

Later in the journals, Larpent begins to give her comments on performances the title of "Observations," again separating them out from more prosaic concerns such as the place of the trip to the theater in her daily routine and underscoring the importance of her critical remarks. On 11 January 1802 she writes:

Evening at the Play Henry $4^{\text {th }}$. home starved with Cold. to bed past 12 .

Observations

Palmer acted Falstaff. flatly. Kemble acted Hotspur excellently. understood his part perfectly. C. Kemble acted the Pr. of Wales Well as to correctness, ill as to conception of the part, indeed it seems contrary to his nature to feel it, \& to his Angular figure to Express it. - I was very well amused. (4:4r)

This again has the effect of emphasizing her evaluations of the productions she sees and suggesting that she had other readers in mind for these accounts.

\section{Shakespeare on the page}

Larpent's assured critical tone in her observations on stage performance is echoed by her responses to her reading of Shakespeare and she frequently offers commentary on the plays she studied at home. On 5 November 1797, for example, she notes that having read King John she finds it "a Strangely put together play - but there are some very fine Speeches" $(2: 191 \mathrm{v})$. The following year she read 2 Henry $I V$ with which she was

much pleased tho' I have often read it There are some very fine Speeches $-\&$ none more truly in character than Henry the $5^{\text {th }}$ to Falstaff where he tells him almost in his old facetious Strain The grave opens 3 times wider for him than for other men - then recalling his dignity he checks the ready Joke and becomes the King - (10 October 1798, $2: 302 r$ ) 
A week later she followed up with Henry $V$, but considered this "a poor drama. One I think of Shakespeares Worst" although she admitted that it contains "Some fine and forcible Speeches" (17 October 1798, 2:306v). In later volumes she often marks such comments with a manicule, again singling out her critiques as worthy of attention.

Shakespeare also seems to permeate her responses to other literary texts, both on the page and on the stage. On reading Elizabeth Helme's romance St. Clair of the Isles; or, The Outlaws of Barra (1803), Larpent proclaims it contains "something of the Quaker phraseology mixed up with some Shakespearian dialogue" and the character De Bourg "reminds one of Falconbridge \& has a something of Benedick" (31 December 1803, 5:165r). And on seeing a performance of Robert Jephson's play The Law of Lombardy on 23 February 1779, she comments that

The tale wrought on this is borrowed from Shakespeares of Hero's supposed falseness in Much ado abt Nothing. The plot is therefore borrowed. . . . The Characters of Bireno \& his confidant Ascanio are imitations of Richard $y^{\mathrm{e}} 3^{\mathrm{d}}$. \& Buckingham - but not supported. ... The language is an imitation of Shakespeare degenerating into affectation \& bombast, - too crowded with Similes often beautiful but sometimes the Sense lost by them. $(17: 113 \mathrm{r}-113 \mathrm{v})$

Larpent is not so bardolatrous that she cannot recognize a poor imitation of Shakespeare when she sees one (although she does not acknowledge that Shakespeare himself borrowed elements of his play).

As with seeing his plays staged, in her reading of Shakespeare Larpent often weighs in on important debates of the period. In 1808 she read The Tempest and A Midsummer Night's Dream for the first time in several years and declared that "parts of the last are wretched \& I am sure justify any opinion that could be formed on Vortigern being written by Shakespeare for it cannot be more absurd or Doggrell" (23 September 1808, 7:168r-168v). William Henry Ireland's play, which he claimed was a discovery of a Shakespearean manuscript, had been staged over a decade earlier, in 1796, and published in 1799; by 1808 it had been dismissed as a forgery by James Boaden, Edmond Malone, and others. Nevertheless, Larpent is still interested in the question of what makes a play Shakespearean. Again, she reveals herself to be resistant to bardolatry because she is willing to admit that Shakespeare's writing is not uniformly great, admitting the possibility that Vortigern could be genuine, despite its apparent absurdity. However, she does acknowledge of A Midsummer Night's Dream that "There is some exquisite light poetry too in it, Some lines full of image, $\&$ in the fairy part Much prettiness of thought" and concedes that "much of the satire on other plays \& the humour is lost to us" (7:168v).

Further evidence that Larpent was keen to keep up with current literary (as well as theatrical) issues can be seen from the fact that her diaries also record that she read a variety of Shakespeare criticism. On 17 April 1800, for example, she read two essays in the periodical the Mirror, which she found "a very Elegant examination of the Character of Hamlet \& in many points Apparently Just" (3:190v). ${ }^{7}$ On 7 June 1808 she read Malone's preface to Shakespeare and then Johnson's, in order to compare them (7:153r). As with her theatrical criticism, Larpent has a clear authorial voice and evidently writes with an audience in mind. In her role as Shakespeare critic, Larpent 
often enters into dispute with established Shakespeare scholars in her journals, for example in her reading of Schlegel on Shakespeare. She accuses Schlegel of excessive bardolatry, claiming he "sees no faults in any of his Dramas He even receives the rejected ones." She also takes issue with the critic's evaluation of costume:

I cannot Subscribe to his position that the keeping up the Costume in dress Scenes \&c which he calls being Mannerist takes off of the poetic effect \& I can remember seeing Garrick act Hamlet in a Velvet full suit \& Macbeth the same with Lady Macbeth in our Court dress. \& the effect it had upon me then - Compared to the consistency now of the more picturesque Northern and Scottish dress. I think him wrong and prejudiced [towards] the poem \&c. (21 September 1816, 9:283v-284r)

Here Larpent reveals her support for Kemble's continuation of Charles Macklin's efforts (in his 1773 production) to costume the play according to the time and place in which it is set. The underlining in her last sentence emphasizes her disagreement with Schlegel and her eagerness to express it to her readers.

Larpent's views on the issue of costume are founded on her own experience of Shakespeare in performance and by keeping the stage uppermost in her mind, even when reading the plays at home, she in fact goes some way here to counteracting the view expressed by many canonical male critics of her era that Shakespeare was better read than acted. Charles Lamb, for example, famously claimed that acting the plays in fact debases them: "When the novelty is past, we find to our cost that, instead of realising an idea, we have only materialised and brought down a fine vision to the standard of flesh and blood" (113). Larpent's interest in Shakespeare on the stage informs her appreciation of his works on the page and she does not consider one form of engagement as inferior to another.

In her carefully planned and meticulously recorded reading, Larpent also takes the opportunity to compare the national poet of England with that of France by reading Voltaire's La Mort de César alongside Shakespeare's Julius Caesar. She clearly prefers the English dramatist's rendering of the story, commenting on Voltaire's play:

Here is no love. but here is great mistake in giving interest to the character of Brutus. In Shakespeare his feelings his doubts are beautiful touches of nature in Voltaire the disclosure from Cesar of their relationship takes off the admiration one may feel for Brutus, he becomes a parricide - Whereas in the other case, gratitude struggles as a Selfish feeling with what he deemed duty to his country. The incidents have no relief, the 3 acts are a mere Story of a conspiracy $-\&$ that against a man determined to reign. There are fine declamatory speeches, but no interest raised $-\&$ Mark Antony is a poor imitation of Shakespeares. (11 December 1811, 8:230v)

In comparison, she praises Shakespeare's play, although she does acknowledge its faults: "What uncommon knowledge of the human heart, \& of Mankind appear in this tragedy amidst uncouth management, bad puns \& confused action. how glow ${ }^{\mathrm{g}}$ are the similes, how Strong \& well put the observations" (16 December 1811, 8:231v). Here Larpent aligns herself with a tradition of Shakespeare criticism by women as well as by men. Elizabeth Montagu's Essay on the Writings 
and Genius of Shakespear (1769) aimed not only to explore the genius of Shakespeare but also to refute Voltaire's criticism of his writings and to compare his works with the Greek and French dramatists in order to demonstrate Shakespeare's superiority. Montagu devoted a chapter of her study to comparing Corneille's Cinna with Shakespeare's Julius Caesar (as Voltaire had encouraged this comparison in translating Shakespeare's play into French), concluding, with nationalistic fervor, that the English dramatist's play was superior to the French playwright's. Larpent is here writing in the same vein. She in fact records having read the works of several women writers and was probably influenced and inspired by the proliferation of literary criticism by women that appeared during her lifetime. Larpent read Montagu's letters (in which she developed many of her critical ideas) in July 1809 (soon after they were published), as well as Elizabeth Carter's works, memoirs, and correspondence in 1808.

Larpent's reading of Voltaire's Semiramis also gives rise to a comparison with Shakespeare: she deems the ghost in this play "an apparition much more exceptionable than those formed by Shakespeare which are beautifully interwoven in his plays as belonging to disordered minds weakened by guilt. Macbeth alone amidst his guests sees Banquo \& the dagger. Brutus only, sees Cesar. - Richard dreams of those he murdered; but here Minus, scares a whole nation" (2 January $1813,8: 237 \mathrm{v}$ ). The nature of Shakespeare's supernatural beings was another issue that had frequently been debated throughout the eighteenth century, including by Montagu in her Essay, which devoted a chapter to consideration of "the Praeternatural Beings." In evaluating Hamlet, Larpent declares herself "extremely affected \& pleased with the Scenes between Horatio, Hamlet, the Spirit. $S^{\mathrm{r}} \mathrm{Edw}^{\mathrm{d}}$ Barry used to say if there ever were Witches Shakespeare saw \& described them - So of Spirits - It is impossible to offer a Sublimer idea of one than in these Scenes" (22 August 1799, 3:77v). Montagu had analyzed this part of the play in detail and admired the "pity and terror ... imparted by the Ghost" (63). Similarly, in her notes on Macbeth in performance Larpent claimed that the singing and dancing added for the witches in the adaptation by Davenant lacked "the terrific grandeur Shakespeare meant" (7 December 1803, 5:151r). Thus in both her reading and her viewing of Shakespeare, Larpent upholds the significance of this important aspect of the playwright's dramaturgy.

\section{Shakespeare and education}

Reading Shakespeare formed a central part of the Larpents' domestic life, with the plays being read aloud in the family and undoubtedly discussed. For example, her comments on the Ghost in Hamlet come after her son George read the play aloud at home in 1799. Similarly, on 24 October 1815 her husband read King John to her and she noted down her favorite parts: "Some of the language \& management of this play is execrable some wonderful. Falconbridges Speech on Commodity - the passionate grief of Constance the whole conduct of John towards Arthur. the scenes with Hubert. description of the Tumults \& their effects on the populace" $(9: 190 \mathrm{v})$. Enjoyment of the reading of Shakespeare was something that had to be cultivated, however: when Larpent read aloud two acts of The Merry Wives of Windsor to her stepson Seymour when he was fourteen years of age, "He did not understand the Humour of Shakespeare, and his fat Knight. He yawned. I left off”'(5 January 1790, 1:2v).

Larpent also considers Shakespeare central to education. This is apparent when she writes about the relationship with the dramatist that she tries to develop in the young people in her life. In 
particular, the history plays are, for Larpent, an important part of a young person's education. In her "Methodized Journal" (volume seventeen of the diaries, a retrospective account of her life before her marriage), Larpent details her "Plan - (\& method of carrying it on) of my Sisters Education commenced Octr $1^{\text {st }}$. 1778," a reading list for her fourteen-year-old sister, Clara (17:106r). Clara was only two years old when their mother died and on the death of their father in 1776, Larpent was left in charge of her sister's upbringing (Cody), a responsibility that she seems to have taken very seriously. Larpent was well-read in French, Latin, history, and natural sciences (Cody) and may have inherited her passion for learning from her father, James Porter, who despite his "slight education" became fluent in French and Italian, distinguished himself as a public speaker, and devoted himself to studying science and literature (Barker). Larpent tried to instill this love of learning in her sister and her children: as well as educating Clara, she later also tutored her stepson and two sons (Cody).

Interestingly, the reading list Larpent develops for her sister includes "Shakespeares historical plays only" (17:107r). The histories are clearly seen as an effective way of teaching about the past but Shakespeare's other works are initially excluded from a young girl's education. By 1780, Larpent had decided that Clara (now eighteen) was ready to move on to "Macbeth King Lear. \& a few of Shakespeares plays in English" to continue her study of poetry (17:165v). Perhaps Larpent thought that Clara needed to develop her critical faculties before focusing on Shakespeare's language, rather than the plots of the plays. Or perhaps certain of Shakespeare's works were considered unsuitable for young female readers. Thomas and Henrietta Bowdler, who were in fact family friends of the Larpents, did not publish their expurgated Family Shakespeare until 1807 but Larpent already seems to sense the need for such a volume. Indeed, she purchased a copy when it was published, using it for her own Shakespeare reading and that of her sons. ${ }^{8}$ Larpent also considered the history plays as particularly significant in the education of her sons. On 5 November 1797, she read King John "hearing there was some intention of acting it at Cheam [her sons' school]" (2:191v). Then on 19 December 1797 "The Boys repeated parts of King John, \& Richard the $2^{\mathrm{d}} \&$ we read over Speeches of Shakespeare" (2:205v). Of course Shakespeare was also considered important to education in more formal settings as his works were studied, and even performed, in schools. Larpent records two visits to see school plays and both are Shakespearean dramas. In 1794 she saw Coriolanus at Cheam and in 1795 Larpent and her husband "drove to Hackney, to the play by Newcome's boys. The Merchant of Venice. really admirably acted. . . The Scenes decorations, dresses, management all very well" (17 June 1794, 1:194r; 5 May 1795, 1:218v). Such school performances of Shakespeare were common in the period. ${ }^{9}$

In seeing a particular value in Shakespeare's history plays, Larpent follows a notable female tradition stretching back to the Shakespeare Ladies Club of the early eighteenth century. During the two theatrical seasons between 1736 and 1738, this group of women petitioned the theater managers for more Shakespeare on the stage and an analysis of the dramatic records of the period makes clear that they most frequently requested Shakespeare's English histories (Ritchie 142-56). Eight Shakespeare plays were revived in this period, five of which (2 Henry IV, Henry V, 1 Henry VI, King John, Richard II) were history plays (six if we include Cymbeline, set in ancient Britain). In the 1737-38 season at Covent Garden theater alone, twenty-four out of a total of forty-three Shakespeare performances were of English history plays as a result of the Shakespeare Ladies' requests. A few years later, James Ralph praised the Club's nationalistic 
aims: "Our great Concern ... ought to be, encouraging old Plays, that abound with a truly British Spirit, and which if ever Foreigners come to understand them, may speak us a brave, honest and free People. This is still in our Power, and the Ladies of the Shakespear Club, gave a very noble Instance of it being their Inclination" (44).

Later in the eighteenth century, Montagu's Essay on the Writings and Genius of Shakespear (1769) saw these plays specifically as having an instructive purpose: "The poet collects, as it were, into a focus those truths, which lie scattered in the diffuse volume of the historian, and kindles the flame of virtue, while he shews the miseries and calamities of vice" (20). Montagu argues that not only do the history plays teach us about the events of the past, their impact is heightened by the audience's connection with the characters and places depicted:

The common interests of humanity make us attentive to every story that has an air of reality, but we are more affected if we know it to be true; and the interest is still heightened if we have any relation to the persons concerned. Our noble countryman, Percy, engages us much more than Achilles, or any Grecian hero. The people for whose use these public entertainments should be chiefly intended, know the battle of Shrewsbury to be a fact: they are informed of what has passed on the banks of the Severn; all that happened on the shore of the Scamander has to them the appearance of a fiction. $(21)^{10}$

Larpent's journal confirms that women had a particular moral interest in the histories and in using Shakespeare for educative purposes as well as for entertainment. The promotion of Shakespeare's history plays therefore allowed women to style themselves as guardians of public morality.

\section{Censorship}

As this survey of Larpent's relationship with Shakespeare demonstrates, she was a fairly typical bourgeois consumer of his works, engaging with them in a variety of forms. Like many other women of the time, she saw the plays staged, read them alone and aloud with her family, and often discussed them, as well as thought carefully about their place in moral education. What is remarkable about Larpent's connection with Shakespeare is that she documents it so carefully in her diaries, apparently with the conviction that others will value her assessments. Furthermore, Larpent's critical responses to Shakespeare are shaped by her wide-ranging reading of other writers and of the burgeoning field of Shakespeare criticism. One of the most important roles that Larpent performs in her diaries was not at all typical: that of dramatic censor. Since the Licensing Act of 1737 (which remained in force until 1968), the manuscripts both of new plays and old ones that had been revised which were intended for performance in London or the provinces had to be submitted to the Examiner for licensing, and it was the job of Larpent's husband, John, to read and approve each of these playtexts. ${ }^{11}$ John Larpent also collected these scripts and kept them as his personal property; these now form the Larpent Collection of Plays at the Huntington Library, consisting of over 2,500 items. Larpent's diaries offer evidence that she helped her husband in his professional capacity as Examiner of Plays. For example, on 2 February 1790 she notes that she has compiled a catalogue "of all the Plays that have been licensed, since the Institution of the Office $\mathrm{M}^{\mathrm{r}}$. Larpent holds of Licenser" (1:5v). Furthermore, 
Larpent also undertook some of the work of Examiner herself: John Larpent was not proficient in Italian but Anna was so she undertook all censoring of Italian operas (Cody). On 15 May 1794, for example, Larpent notes that she "read the Italian Opera for Mr L to licence" (1:189r). ${ }^{12}$ There is at least one piece of evidence in the Larpent collection to show that Anna in fact licensed plays independently: the manuscript copy of The Virgin of the Sun states on its title page "Approved AML" (LA 1868). Furthermore, it seems that her influence over the play scripts was well known: on 12 April 1792, Larpent notes that Eliza Parsons "applied to me for support in a Farce She has written" (1:50r). Larpent expressed her discomfort with Parsons's attempt to sway her: "I cannot support her for She is unprincipled in her Conduct." But the play, The Intrigues of a Morning; or, An Hour in Paris (based on a work by Molière), was performed twice at Covent Garden that season.

Just as Shakespeare's plays were frequently read aloud at the Larpents' home as a communal activity, so too were the manuscripts submitted for censorship: Larpent frequently spent evenings at her needlework while John read a play to her and the diaries occasionally record Clara reading aloud as well. Given that these manuscripts were submitted for the Examiner's approval, debate about the merits of the plays must have ensued. On 18 January 1803, Larpent records her observations on a drama read aloud to her by her husband called Hear Both Sides: "I believe it by Holcroft it is a very heavy play - relieved only by biting Sarcasms - and those obscured by gloomy Misanthropy. I think the abuse it conveys on Lawyers which is lamely enough done away at the end Should prevent its being acted in its present form" $(5: 6 \mathrm{v}) .{ }^{13}$ The possibility of debate about the manuscript in the Larpent household is evident here from the fact that she underlines and emphasizes the "I" in the second sentence. The focus on her own opinion and the fact that it is perhaps at odds with the view of others is similar to her review of Master Betty from 1805 quoted above ("I differ from many - I think there is so much mind about him ..."). Perhaps Larpent's husband did not agree on the need for censorship in the case of Hear Both Sides but Larpent was certainly keen to express her opinions on the matter to him. In fact, John Larpent usually made his decision on a play on the same day or soon after such a reading with his wife, which strongly suggests that he consulted her before deciding whether or not to sign a license. ${ }^{14}$

Larpent's comments on the plays submitted for licensing suggest that she often analyzed them as carefully as she did Shakespeare's works, commenting on the dramatic and literary merit of the texts. Her observations also demonstrate that the stage was always in her mind when she read the manuscript plays as she often remarks on their suitability for performance. This can be seen from her comments on a drama based on Walter Scott's novel Guy Mannering on 28 February 1816:

I cannot tell whether I was not biased in being interested as I heard this 3 act drama by the recollection of the scenes described in the Novel. I certainly think the Story better wrought up into the Space necessary for the theatre than could have been expected - the Scenes must be very fine $-\&$ Music if well adapted to the words pleasing - the characters are rather insipid on the Stage except Dimot \& Meg. As to Abel Sampson who in the Novel relieves the narrative $\&$ offers original traits of character on the stage he is a forced Caricature \& seen at once cannot be well understood or liked. (9:227r)

She is concerned with exactly how the material will be made fit for performance, as opposed to 
reading, advocating attention to scenery and music (also key concerns for Larpent when writing about Shakespeare on the stage, as we see in her comments on the 1816 performance of The Tempest previously cited) to make the play more likely to succeed. Her keen consideration of the relationship between the page and the stage develops from her interest in Shakespeare and the criticism of the period which debated the merits of performing his works, whilst his plays nevertheless remained a core part of the theatrical repertoire.

Much of Larpent's criticism of manuscript plays refers to their potential success, or lack of it, in the theater. The play The Step Mother, for example "has merit. Yet it may act heavily" (12 February 1814, 9:3r). Of James Kenney's The City Rivals, she comments, "When well directed and in safe honest keeping. - I should suppose this Play would Succeed" (5 March 1814, 9:6v). Isaac Pocock's Jean de Bart, which "ends by a fight and the blowing up a Danish Frigate" causes Larpent some concern: "How will this take \& be executed?" (19 October 1815, 9:187v). Larpent is attuned to the practicalities of staging as well as the dramatic merits of the pieces she reads. Her reservations about this particular work might be on practical grounds but in general she has a distaste for spectacle, despite its popularity on stage in the period. This extended to the performance of Shakespeare: in an extract discussed above Larpent critiqued Dryden and Davenant's alteration of the "simplicity" of The Tempest into "brilliant spectacle."

The diary also contains evidence that Larpent's assessment of works submitted for licensing concurs with the response of playgoers: on 20 January 1808 she comments on a manuscript play by Prince Hoare entitled Something To Do that it is "Intolerable Stuff. A farce of 5 Acts, absurd - a Jumble of German Scenery \& Characters in the Masquerade of English habits \& manners, caricatures throughout. yet So ridiculous that if 'tis permitted it can only be because people must laugh at it as at Punch and his wife Joan" (7:132v). An insertion above this entry reads: "My judgment right on this played [sic] quite condemned $1^{\text {st }}$. night." Larpent's detailed engagement with Shakespeare in a multiplicity of forms qualifies her to enact the quasi-official role of Examiner of Plays alongside her husband: her thinking about what makes a successful performance when watching his plays on the stage and her evaluation of the literary merit of his works when she reads them alongside criticism enables her to judge the plays submitted for licensing in terms of what will succeed in the theater and what will achieve longevity as a dramatic work. ${ }^{15}$

\section{Conclusions}

Drama in general, and Shakespeare in particular, was crucial to Larpent and formed a central part of both her domestic life and her intellectual development. Larpent's interest in performance in her writings reveals that she was a sophisticated critic of dramatic writing, aware of its dual nature as a genre both read in private in the study and performed in public on the stage. The abundance of references to Shakespeare in the diaries and the sheer variety of ways in which he is encountered demonstrate that Shakespeare was "part of an Englishwoman's constitution" (Austen 390-91). This phrase stems from another writer whose works Larpent read and enjoyed, Jane Austen. ${ }^{16}$ Through the character of Henry Crawford in Mansfield Park (1814), Austen pokes fun at those who become "acquainted with [Shakespeare] without knowing how" because "[h]is thoughts and beauties are so spread abroad that one touches them everywhere, one is intimate with him by instinct" (390-391). Larpent's writing, however, reveals a sustained and 
thoughtful attention to Shakespeare in a variety of forms. The detailed engagement with Shakespeare outlined in this essay made Larpent's unconventional work as theater censor possible. 
Works Cited

Austen, Jane. Mansfield Park. Ed. John Wiltshire. Cambridge Edition of the Works of Jane Austen. Cambridge UP, 2005.

A Woman's View of Drama, 1790-1830: The Diaries of Anna Margaretta Larpent in the Huntington Library. A Listing and Guide to the Microfilm Collection. Marlborough: Adam Matthew, 1995.

Barker, G. F. R. "Porter, Sir James (1710-1776)." Rev. R. D. E. Eagles. Oxford Dictionary of National Biography. http://www.oxforddnb.com.proxy3.library.mcgill.ca/view/article/22569

Brewer, John. "Reconstructing the Reader: Prescriptions, Texts and Strategies in Anna Larpent's Reading." The Practice and Representation of Reading in England. Ed. James Raven, Helen Small, and Naomi Tadmor. Cambridge UP, 1996, pp. 226-45.

---. The Pleasures of the Imagination: English Culture in the Eighteenth Century. HarperCollins, 1997.

Cody, Lisa Forman. "Larpent, Anna Margaretta (1758-1832)." Oxford Dictionary of National Biography. http://www.oxforddnb.com.proxy3.library.mcgill.ca/view/article/65588

Colombo, Claire Miller. “'This Pen of Mine Will Say Too Much:' Public Performance in the Journals of Anna Larpent." Texas Studies in Literature and Language, vol. 38, no. 3/4, 1996, pp. 285-301.

Conolly, L. W. "The Censor's Wife at the Theater: The Diary of Anna Margaretta Larpent, 1790-1800." Huntington Library Quarterly, vol. 35, 1971, pp. 49-64.

Cox, Jeffrey N. "Baillie, Siddons, Larpent: Gender, Power, and Politics in the Theater of Romanticism." Women in British Romantic Theater: Drama, Performance, and Society, 17901840. Ed. Catherine Burroughs. Cambridge UP, 2000, pp. 23-47.

Davies, Thomas. Dramatic Micellanies [sic]: Consisting of Critical Observations on Several Plays of Shakespeare, 3 vols. London: 1783-84.

De Bruyn, Frans. "Shakespeare and the French Revolution." Shakespeare in the Eighteenth Century. Ed. Fiona Ritchie and Peter Sabor. Cambridge UP, 2012, pp. 297-313.

The Freemasons' Magazine: or, General and Complete Library. February 1795, pp. 135-38.

Genest, John. Some Account of the English Stage. 10 vols. Bath, 1832.

Haywood, Ian and John Halliwell. "Romantic Spectacle - An Introduction." Romanticism on the Net, vol. 46, 2007. http://id.erudit.org/iderudit/016128ar 
Highfill, Philip H., Jr, Kalman A. Burnim, and Edward A. Langhans. "Siddons, Mrs William, Sarah, née Kemble, 1755-1831, actress, singer." A Biographical Dictionary of Actors, Actresses, Musicians, Dancers, Managers \& Other Stage Personnel in London, 1660-1800, 16 vols.

Southern Illinois UP, 1973-93, vol. 14, pp. 1-67.

Hunt, Leigh. “Mr. Young's Merits Considered.” Leigh Hunt's Dramatic Criticism, 1808-1831. Ed. Lawrence Huston Houtchens and Carolyn Washburn Houtchens. Columbia UP, 1949, pp. 21-25.

Lamb, Charles. "From 'On the Tragedies of Shakespeare, Considered with Reference to their Fitness for Stage Representation' (1811).” The Romantics on Shakespeare. Ed. Jonathan Bate. Penguin, 1992, pp. 111-27.

Larpent, Anna. Diaries. Huntington Library MS HM 31201. 17 vols.

Larpent Collection of Plays. Huntington Library MSS LA 1-2503.

MacMillan, Dougald. Catalogue of the Larpent Plays in the Huntington Library. San Pasqual P, 1939.

Montagu, Elizabeth. "An Essay on the Writings and Genius of Shakespear (1769)." Bluestocking Feminism: Writings of the Bluestocking Circle, Volume 1: Elizabeth Montagu. Ed. Elizabeth Eger. Gen. ed. Gary Kelly. Pickering and Chatto, 1999, pp. 1-113.

Morris, Marilyn. "Negotiating Domesticity in the Diaries of Anna Larpent." Journal of Women's History, vol. 22, no. 1, 2010, pp. 85-106.

Ralph, James. The Case of our Present Theatrical Disputes, Fairly Stated. London, 1743.

Ranger, Paul. "Betty, William Henry West (1791-1874).” Oxford Dictionary of National Biography. http://www.oxforddnb.com/view/article/2315

Ritchie, Fiona. Women and Shakespeare in the Eighteenth Century. Cambridge UP, 2014.

\footnotetext{
${ }^{1}$ Biographical details and quotations here are taken from Cody's entry in the $O D N B$.

${ }^{2}$ The diaries have been microfilmed and, more recently, digitized in Adam Matthew's Eighteenth-Century Drama: Censorship, Society, and the Stage collection. However, they are still not widely accessible. This article is based on a study of the diaries in manuscript. Volume 17, Larpent's "Methodized Journal" (a retrospective account of her life before her marriage), was written from notes "always roughly taken." But Larpent claims that she has "merely . . . Methodized my hurried Entries - Scarcely altering a Word. - Never the Sense." (17:4r)

${ }^{3}$ Larpent's diaries are here referenced by volume and folio number. I have retained the orthography and punctuation of the originals (in which there are many irregularities).

${ }^{4}$ In their Introduction to a special issue of Romanticism on the Net on Romantic Spectacle, Haywood and Halliwell write of "[s]pectacle's association with excess, sensationalism, populism and commercialism" (par. 4), a connection which Larpent apparently upholds. However, they also note that much Romantic spectacle was cutting edge, employing "new and innovative visual technologies" (par. 3).

${ }^{5}$ Colombo analyzes the diaries as a form of linguistic performance but does not focus on drama or Shakespeare. For a discussion of the tension between Larpent's scholarly inclinations and her domesticity, see Morris.
} 
${ }^{6}$ Colombo similarly concludes that "all observations of a scholarly nature are set off by quotation marks from more mundane recitations of domestic routine" (292).

${ }^{7}$ These were presumably the influential essays published in 1780 by Henry Mackenzie, editor of the Mirror.

${ }^{8}$ Larpent records reading from the Family Shakespeare herself in September 1808 (7:168r). In April 1827 she heard her son George (now in his thirties) read aloud from it $(14: 52 \mathrm{v})$. This suggests that the edition remained important to the family. After 1807, subsequent editions of the Bowdlers' work were published with a subtitle which made its mission even clearer: "in which nothing is added to the original text; but those words and expressions are omitted which cannot with propriety be read aloud in a family."

${ }^{9}$ For example, De Bruyn discusses headmaster Richard Valpy's adaptations of Shakespeare for his students at Reading School to perform (304-7).

${ }^{10}$ See also Ritchie 73-77.

${ }^{11}$ For a discussion of Anna Larpent's role as the censor's wife, see Cox.

12 This was presumably the Italian comic opera Il Burbero di Buon Cuore (LA 1023), which was produced at the King's Theatre, Haymarket on 17 May 1794 (MacMillan 169).

${ }^{13}$ The manuscript plays were often submitted for licensing anonymously and it becomes something of a game for Larpent and her husband to try to ascertain the author. Here she correctly conjectures that it is by Thomas Holcroft.

${ }^{14}$ The Examiner did not always record the date on which he licensed a play but when he did, it is strikingly close to his wife's reading of the manuscript. For example, Anna read the comic opera Just in Time (LA 947) on 30 April 1792 (1:53v) and John dated the play as licensed on 1 May (MacMillan 157). For the dates of John Larpent's licenses see MacMillan.

${ }^{15}$ It should be noted that Larpent also records seeing, reading, and discussing a variety of other works in the diaries in addition to Shakespeare and the plays submitted for licensing. Space does not permit a detailed consideration of the many contemporary and classic dramatic works she writes about but a more detailed study of this material in the diaries would certainly be fruitful. For extracts that record trips to the theater from the first three volumes of the diaries, see Conolly. On Larpent as a reader, see Brewer, "Reconstructing the Reader."

${ }^{16}$ Larpent records reading the following Austen novels: Sense and Sensibility (July 1812, 8:203r), Pride and Prejudice (March 1813, 8:249v), Emma (April 1816, 9:247v-248r), Northanger Abbey (January 1818, 10:102r-v), Persuasion (January 1818, 10:103r-v). There is no record of her reading Mansfield Park, however. 